\title{
Pengelompokkan Kelurahan di Kota Surabaya Berdasarkan Kriteria Pembentukan Kampung Keluarga Berencana
}

\author{
Khusnul Khotimah, Vita Ratnasari, dan Madu Ratna \\ Departemen Statistika, Fakultas Matematika, Komputasi, dan Sais Data, \\ Institut Teknologi Sepuluh Nopember (ITS) \\ e-mail: madu_r@statistika.its.ac.id
}

\begin{abstract}
Abstrak-Salah satu upaya yang dilakukan BKKBN untuk membumikan kembali program KKBPK adalah dengan terus membangun Kampung KB di seluruh wilayah Indonesia. Kampung KB merupakan satuan wilayah setingkat RW, dusun atau setara, yang memiliki kriteria tertentu, dimana terdapat keterpaduan program kependudukan, keluarga berencana, dan pembangunan keluarga dan pembangunan sektor terkait. Penelitian ini bertujuan untuk mengelompokkan kelurahan di Kota Surabaya berdasarkan kriteria pembentukan Kampung KB menggunakan analisis klaster sehingga diharapkan dapat membantu untuk menentukan wilayah yang akan dijadikan Kampung KB. Pengelompokkan yang dihasilkan, selanjutnya akan dilakukan analisis One Way MANOVA untuk mengetahui apakah terdapat perbedaan antar kelompok yang terbentuk berdasarkan kriteria pembentukan Kampung KB. Hasil analisis klaster menunjukkan bahwa terbentuk lima kelompok kelurahan di Kota Surabaya berdasarkan kriteria pembentukan Kampung KB serta metode pengelompokkan yang terbaik adalah metode ward's. One Way MANOVA memberikan hasil bahwa terdapat perbedaan rata-rata antar kelompok kelurahan yang terbentuk berdasarkan kriteria pembentukan Kampung KB.
\end{abstract}

Kata Kunci-Analisis Klaster, Kampung KB, One Way MANOVA.

\section{PENDAHULUAN}

$\mathrm{I}$ NDONESIA sebagai negara berkembang juga tidak lepas dari masalah kependudukan. Hasil sensus penduduk menunjukkan bahwa jumlah penduduk Indonesia pada tahun 2000 sebesar 206.264.595 jiwa. Penduduk Indonesia sudah mencapai 237.641.326 jiwa dengan laju pertumbuhan penduduk sebesar 1,49 persen pada tahun 2010 [1]. Laju pertumbuhan penduduk yang tinggi merupakan masalah yang harus ditanggulangi karena mengecilkan arti pembangunan dalam bidang ekonomi. Pemerintah pun telah mencanangkan berbagai program untuk melaksanakan kebijakan kependudukan, salah satunya adalah program keluarga berencana $(\mathrm{KB})$. Keluarga berencana atau KB didefinisikan sebagai upaya mengatur kelahiran anak, jarak dan umur ideal melahirkan, mengatur kehamilan, melalui promosi, perlindungan dan bantuan sesuai dengan hak reproduksi untuk mewujudkan keluarga yang berkualitas [2].

BKKBN untuk membumikan kembali program Kependudukan, Keluarga Berencana, dan Pembangunan Keluarga (KKBPK) adalah dengan terus membangun Kampung KB di seluruh wilayah Indonesia [3]. Kampung KB adalah satuan wilayah setingkat RW, dusun atau setara, yang memiliki kriteria tertentu dimana terdapat keterpaduan program KKBPK dan pembangunan sektor terkait yang dilaksanakan secara sistematik dan sistematis [4].

Kota Surabaya juga sebagai pusat ekonomi di Provinsi Jawa Timur yang menjadi daya tarik bagi penduduk untuk datang sehingga kota ini tidak terlepas dari masalah kependudukan. Untuk meningkatkan kesejahteraan penduduk di Jawa Timur dan khususnya Kota Surabaya dimana masih banyak terdapat kampung kumuh dengan jumlah penduduk yang sangat padat, BKKBN Jawa Timur Perwakilan Surabaya dan Bapemas KB Kota Surabaya juga melakukan pencanangan Kampung KB [5].

Penelitian ini dilakukan untuk mengelompokkan kelurahan di Kota Surabaya berdasarkan kriteria pembentukan Kampung KB. Pengelompokkan tersebut nantinya diharapkan dapat membantu BKKBN untuk menentukan wilayah yang akan dibentuk sebagai Kampung KB. Proses pengelompokan objekobjek didasarkan atas ukuran kesamaan atau ketidaksamaan yang bertujuan untuk mengidentifikasi sekelompok objek yang memiliki kemiripan karakteristik tertentu [6]. Selanjutnya hasil pengelompokkan tersebut akan dilakukan analisis One Way MANOVA sebagai evaluasi dari pengelompokkan yang telah dilakukan. One Way MANOVA merupakan suatu teknik yang digunakan untuk membandingkan rata-rata dua populasi atau lebih dengan variabel dependen lebih dari satu [7].

\section{TINJAUAN PUSTAKA}

\section{A. Statistika deskriptif}

Karakteristik data dapat dideskripsikan dengan membuat statistika deskriptif dari data tersebut. Statistika deskriptif merupakan metode statistik untuk mengumpulkan dan menyajikan data sehingga menghasilkan suatu informasi yang berguna [8].

\section{B. Multikolinieritas}

Multikolinieritas merupakan adanya hubungan linier antar variabel bebas atau variabel prediktor. Variabel bebas dinyatakan tidak ada multikolinieritas jika nilai VIF lebih dari 10 dengan perhitungan sebagai berikut [9]:

$$
V I F_{j}=\frac{1}{T O L}=\frac{1}{1-R_{j}^{2}} ; j=1,2, \ldots, p .
$$




\section{Analisis Klaster}

Analisis klaster merupakan salah satu metode multivariat untuk mengelompokkan $\mathrm{n}$ pengamatan ke dalam $g$ kelompok $(g \leq \mathrm{n})$ yang dilakukan atas dasar kemiripan (similarities) atau ketakmiripan (dissimilarities). Ukuran ketakmiripan yang biasa digunakan adalah jarak Euclidean yang dapat dirumuskan sebagai berikut [7]:

$$
d\left(x_{i}, x_{j}\right)=\sqrt{\sum_{k=1}^{p}\left(x_{i k}-x_{j k}\right)^{2}} .
$$

Teknik pengelompokkan yang digunakan dalam penelitian ini adalah metode hirarki. Metode hirarki merupakan metode dimana terdapat objek-objek yang memiliki kesamaan yang yang bergabung dalam sebuah kelompok.

a) Single Linkage

Single linkage adalah pengelompokkan yang didasarkan pada jarak atau kesamaan antar objek. Jika dua objek memiliki jarak terkecil, maka objek tersebut akan digabungkan menjadi satu kelompok dan demikian seterusnya.

$$
d_{(U V) W}=\min \left\{d_{U W}, d_{V W}\right\}
$$

Keterangan :

$d_{(U V) W} \quad$ : jarak minimum antara kelompok $(U V)$ dan kelompok $W$

$d_{U W} \quad$ : jarak antara kelompok $U$ dan kelompok $W$

$d_{V W} \quad$ : jarak antara kelompok $V$ dan kelompok $W$

\section{b) Complete Linkage}

Complete Linkage adalah pengelompokkan yang sama seperti single linkage namun dengan cara mengelompokkan objek yang memiliki jarak terjauh atau kesamaan yang sedikit. Berikut adalah perhitungan jarak yang digunakan:

$$
d_{(U V) W}=\max \left\{d_{U W}, d_{V W}\right\} .
$$

c) Average Linkage

Average linkage adalah pengelompokkan yang dibentuk berdasarkan nilai rata-rata jarak seluruh individu dalam satu kelompok dengan rata-rata jarak seluruh individu pada kelompok lain.

$$
d_{(U V) W}=\frac{\sum_{i} \sum_{k} d_{i k}}{N_{(U V)} N_{W}} .
$$

d) Metode Ward's

Jarak antar dua kelompok dalam metode ward's adalah jumlah kuadrat antara dua kelompok untuk seluruh variabel. Metode ini mencoba meminimumkan varian dalam kelompok dan cenderung digunakan untuk melakukan kombinasi kelompok-kelompok dengan jumlah yang kecil.

$$
E S S=\sum_{i=1}^{N}\left(\boldsymbol{x}_{j}-\overline{\boldsymbol{x}}\right)^{\prime}\left(\boldsymbol{x}_{j}-\overline{\boldsymbol{x}}\right) .
$$

\section{Pseudo F Statistics}

Pseudo $F$ tertinggi pada beberapa simulasi menunjukkan bahwa kelompok tersebut mampu memberikan hasil yang optimal, dimana keragaman dalam kelompok sangat homogen sedangkan antar kelompok sangat heterogen. Rumus Pseudo F dapat ditulis sebagai berikut [10]:

$$
\text { Pseudo } F=\frac{\left(\frac{R^{2}}{g-1}\right)}{\left(\frac{1-R^{2}}{n-g}\right)}
$$

dengan,

$$
\begin{gathered}
R^{2}=\frac{S S B}{S S T}=\frac{(S S T-S S W)}{S S T}, \\
S S T=\sum_{l=1}^{g} \sum_{j=1}^{n_{l}} \sum_{k=1}^{p}\left(x_{l j k}-\bar{x}_{k}\right)^{2} \\
S S W=\sum_{l=1}^{g} \sum_{j=1}^{n_{l}} \sum_{k=1}^{p}\left(x_{l j k}-\bar{x}_{l k}\right)^{2}
\end{gathered}
$$

Keterangan :

$g \quad$ : banyaknya kelompok

$n_{l} \quad$ : banyaknya anggota pada kelompok ke- $l$ untuk $l=1,2, \ldots, g$

$\bar{x}_{k}$ : rata-rata keseluruhan objek pada variabel ke- $k$ untuk $k=1,2, \ldots, p$

$\bar{x}_{l k}$ : rata-rata kelompok ke-l pada variabel ke-k untuk $l=1,2, \ldots, n_{l}$ dan $k=1,2, \ldots, p$

\section{E. Rasio $S_{w}$ dan $S_{b}$}

Hasil kinerja untuk variabel pengelompokkan dengan tipe data numerik dapat dijelaskan dengan rasio nilai dari standar deviasi didalam kelompok $\left(S_{w}\right)$ dan standar deviasi antar kelompok $\left(S_{B}\right)$. Kinerja metode pengelompokkan terbaik adalah ketika memiliki nilai ratio antara dan terkecil, artinya bahwa terdapat maksimum homogenitas didalam kelompok dan maksimum heterogenitas antar kelompok [11].

$$
S_{w}=\frac{1}{C} \sum_{c=1}^{C} S_{c}
$$

dengan $S_{c}$ adalah standar deviasi dari kelompok ke-c dan C adalah jumlah kelompok yang terbentuk.

$$
S_{B}=\left[\frac{1}{C-1} \sum_{c=1}^{C}\left(\bar{x}_{c}-\bar{x}\right)^{2}\right]^{1 / 2}
$$

dengan merupakan rata-rata dari semua kelompok ke-c dan merupakan rata-rata keseluruhan kelompok. Kinerja suatu metode pengelompokkan semakin baik ketika nilai rasio antara dan semakin kecil.

\section{F. Pengujian Asumsi Distribusi Normal Multivariat}

Salah satu pengujian distribusi normal multivariat yang dapat dilakukan adalah menggunakan pengujian Shapiro-Wilk dengan hipotesis dan statistik uji sebagai berikut [12]:

Hipotesis :

$\mathrm{H}_{0}: F(X)=\boldsymbol{N}(\boldsymbol{\mu}, \boldsymbol{\Sigma})$ data berdistribusi normal multivariat

$\mathrm{H}_{1} \quad: F(X) \neq N(\mu, \Sigma)$ data tidak berdistribusi normal multivariat 
Statistik uji :

$$
\begin{gathered}
W^{*}=\frac{1}{m} \sum_{i=1}^{m} W_{o} \\
W_{o}=\frac{d^{2}}{S^{2}} \\
S^{2}=\sum_{t=1}^{n}\left(\hat{a}_{t}-\overline{\hat{a}}_{t}\right)^{2} \\
d=\sum_{t=1}^{n} g_{t} \hat{a}_{(t)}
\end{gathered}
$$

Dengan taraf signifikan $\alpha$ yang digunakan, $\mathrm{H}_{0}$ ditolak apabila $W^{*}<c_{\alpha ; n, p}$ sehingga data dikatakan tidak berdistribusi normal multivariat. Nilai $g$ adalah nilai koefisien dari tabel normality test dan $c_{\alpha ; n, p}$ diperoleh melalui simulasi Monte Carlo.

\section{G. Asumsi Homogenitas}

Salah satu asumsi yang harus dipenuhi dalam membandingkan dua atau lebih vektor rata-rata adalah seluruh populasi memiliki matriks kovariansi $(\boldsymbol{\Sigma})$ yang sama. Pengujian homogenitas ini dapat dilakukan dengan melakukan pengujian Box's M [13]. Hipotesis yang digunakan adalah sebagai berikut.

$\mathrm{H}_{0}: \boldsymbol{\Sigma}_{1}=\boldsymbol{\Sigma}_{2}=\cdots=\boldsymbol{\Sigma}_{g}=\boldsymbol{\Sigma}$ (matriks varians kovarian homogen)

$\mathrm{H}_{1}$ : $\quad$ minimal ada satu $\Sigma_{l} \neq \Sigma$ untuk $l=1,2, \ldots, g$ (matriks varians kovarian tidak homogen)

Statistik uji :

$$
\begin{gathered}
C=(1-u) M \\
M=\left\{\left[\sum_{l}\left(n_{l}-1\right)\right] \ln \mid \text { Spooled } \mid-\sum\left[\left(n_{l}-1\right) \ln \left|\mathbf{S}_{l}\right|\right]\right\} \\
u=\left[\sum_{l} \frac{1}{\left(n_{l}-1\right)}-\frac{1}{\sum_{l}\left(n_{l}-1\right)}\right]\left[\frac{2 p^{2}+3 p-1}{6(p+1)(g-1)}\right] \\
\mathbf{S}_{\text {pooled }}=\frac{1}{\sum_{l=1}^{g}\left(n_{l}-1\right)}\left[\sum_{l=1}^{g}\left(n_{l}-1\right) \mathbf{S}_{l}\right]
\end{gathered}
$$

Hipotesis nol akan ditolak apabila nilai statistik uji $\mathrm{C}>\chi_{p(p+1)(g-1) / 2(\alpha)}^{2}$.

\section{H. One Way MANOVA}

One way Multivariate Analyze of Varians (MANOVA) adalah suatu teknik yang digunakan untuk membandingkan rata-rata dua populasi atau lebih dengan variabel dependen

\begin{tabular}{|c|c|c|}
\hline Source of Varians & $\begin{array}{c}\text { Matrix of Sum of Squares and } \\
\text { cross product }(S S P)\end{array}$ & $\begin{array}{c}\text { Degrees } \\
\text { of } \\
\text { freedom }\end{array}$ \\
\hline Treatment & $\mathbf{B}=\sum_{l=1}^{s} n_{l}\left(\overline{\mathbf{x}}_{l}-\overline{\mathbf{x}}\right)\left(\overline{\mathbf{x}}_{l}-\overline{\mathbf{x}}\right)^{\prime}$ & $g-1$ \\
\hline Residual & $\mathbf{W}=\sum_{l=1}^{g} \sum_{j=1}^{n_{l}}\left(\mathbf{x}_{l j}-\overline{\mathbf{x}}_{l}\right)\left(\mathbf{x}_{l j}-\overline{\mathbf{x}}_{l}\right)^{\prime}$ & $\sum_{l=1}^{g} n_{l}-g$ \\
\hline $\begin{array}{l}\text { Total (Corrected } \\
\text { for the mean) }\end{array}$ & $\mathbf{B}+\mathbf{W}=\sum_{l=1}^{g} \sum_{j=1}^{n_{l}}\left(\mathbf{x}_{l j}-\overline{\mathbf{x}}\right)\left(\mathbf{x}_{l j}-\overline{\mathbf{x}}\right)^{\prime}$ & $\sum_{l=1}^{g} n_{l}-1$ \\
\hline
\end{tabular}
lebih dari satu [7]. Uji perbedaan rata-rata anatar kelompok menggunakan statistik uji wilk's lambda. Berikut adalah hipotesis yang digunakan dalam pengujian perbedaan rata-rata.

$\mathrm{H}_{0}: \tau_{1}=\tau_{2}=\cdots=\tau_{g}=\mathbf{0}$

$\mathrm{H}_{1}$ : minimal ada satu $\tau_{l} \neq \mathbf{0}$ dimana $l=1,2, \ldots, g$
Tabel 1.

MANOVA

Statistik uji :

$$
\Lambda^{*}=\frac{|\mathbf{W}|}{|\mathbf{B}+\mathbf{W}|}
$$

Nilai Pillai's Trace dapat dihitung dengan rumus sebagai berikut:

$$
P=\sum_{i=1}^{p}\left(\frac{\lambda_{i}}{1+\lambda_{i}}\right)=t r\left|\frac{\mathbf{B}}{\mathbf{B}+\mathbf{W}}\right|
$$

Nilai F yang bersesuaian dengan statistik uji Pillai's Trace dapat dihitung dengan rumus berikut.

$$
F=\left(\frac{2 h+s+1}{2 m+s+1}\right)\left(\frac{V}{s-V}\right),
$$

Dimana

$$
\begin{gathered}
s=\min (p, q), \\
h=0,5(v-p-1), \\
m=0,5(|p-q|-1),
\end{gathered}
$$

Keterangan :

$$
\begin{array}{ll}
p & : \text { banyaknya variabel } \\
q & : \text { derajat bebas hipotesis } \\
v & : \text { derajat bebas error } \\
V & : \text { Pillai's trace }
\end{array}
$$

Hipotesis nol akan ditolak ketika $F>F$

$$
\alpha\left(g-1 ; \sum_{l=1}^{g} n_{l}-g\right)
$$

\section{Kampung Keluarga Berencana}

Kampung KB adalah satuan wilayah setingkat RW, dusun atau setara, yang memiliki kriteria tertentu, dimana terdapat keterpaduan program kependudukan, keluarga berencana, dan pembangunan keluarga dan pembangunan sektor terkait yang dilaksanakan secara sistematik dan sistematis [4].

Kriteria Kampung KB dideklarasikan menjadi tiga kriteria yang harus dipenuhi. Kriteria utama yang harus terpenuhi terlebih dahulu adalah wilayah calon Kampung KB memiliki jumlah Pra-Keluarga Sejahtera (Pra-KS) dan Keluarga Sejahtera 1 (KS-1) yang tinggi. Kriteria khusus yaitu kriteria pencapaian program KB di wilayah tersebut yang digambarkan melalui jumlah peserta $\mathrm{KB}$ belum cukup tinggi, peserta KB aktif, dan penggunaan metode kontrasepsi jangka panjang yang rendah, serta dengan tingkat unmet need yang tinggi [14]. 


\section{METODOLOGI PENELITIAN}

\section{A. Sumber Data}

Data yang akan digunakan dalam penelitian ini adalah data sekunder. Data diperoleh dari Badan Pusat Statistik Kota Surabaya. Data yang digunakan merupakan data tahun 2015. Unit penelitian dalam penelitian ini adalah 143 kelurahan di Kota Surabaya.

\section{B. Variabel Penelitian}

Variabel yang digunakan dalam penelitian ini sebanyak delapan variabel berdasarkan kriteria pembentukan Kampung KB. Variabel penelitian yang digunakan tersebut akan disajikan pada Tabel 2 berikut ini:

Tabel 2.

Variabel Penelitian

\begin{tabular}{cl}
\hline \hline Variabel & \multicolumn{1}{c}{ Keterangan } \\
\hline$X_{1}$ & Persentase keluarga pra sejahtera \\
$X_{2}$ & Persentase keluarga sejahtera tahap I \\
$X_{3}$ & Persentase bukan pesesrta KB aktif \\
$X_{4}$ & Persentase peserta yang tidak menggunakan Metode \\
& Kontrasepsi Jangka Panjang (MKJP) \\
$X_{5}$ & Persentase kepala keluarga yang tidak bekerja \\
\hline \hline
\end{tabular}

\section{Langkah Analisis}

Berikut adalah langkah analisis dalam pengelompokkan kelurahan di Kota Surabaya berdasarkan kriteria pembentukan Kampung KB.

1. Mendeskripsikan karakteristik kriteria pembentukan Kampung KB dengan analisis deskriptif menggunakan mean, varians, minimum, dan maksimum

2. Mengelompokkan kelurahan di Kota Surabaya berdasarkan kriteria pembentukan Kampung KB menggunakan analisis klaster dengan langkah-langkah sebagai berikut.

- Melakukan deteksi multikolinieritas.

- Mengelompokkan kelurahan di Kota Surabaya dengan metode single linkage, complete linkage, average linkage, dan metode ward's.

- Melakukan perbandingan antara metode pengelompokkan yang digunakan untuk mendapatkan banyaknya kelompok optimum dengan Pseudo $F$ dan metode pengelompokkan yang terbaik dengan kriteria rasio $S_{w}$ dan $S_{b}$.

3. Melakukan evaluasi hasil pengelompokkan menggunakan pengujian One Way MANOVA dengan langkah-langkah sebagai berikut.

- Melakukan pengujian asumsi data berdistribusi normal multivariat.

- Melakukan pengujian homogenitas matriks varians kovarian dengan menggunakan uji Box'M.

- Melakukan pengujian vektor rata-rata untuk mengetahui adanya perbedaan yang signifikan antar kelompok yang terbentuk.

- Mendeskripsikan karakteristik berdasarkan kelompok yang terbentuk dengan menggunakan rata-rata.

4. Melakukan interpretasi hasil analisis dan membuat kesimpulan.

\section{PEMBAHASAN}

\section{A. Statistika Deskriptif}

Berikut adalah karakteristik kelurahan di Kota Surabaya berdasarkan ukuran pemusatan dan penyebaran data. Ukuran pemusatan data yang digunakan yaitu rata-rata (mean), minimum, maksimum, dan ukuran penyebaran data yang digunakan yaitu varians.

Tabel 3.

Statistika Deskriptif Kriteria-Kriteria Pembentukan Kampung KB

\begin{tabular}{|c|c|c|c|c|}
\hline Variabel & Mean & Varians & $\begin{array}{r}\text { Minimu } \\
\mathrm{m}\end{array}$ & Maksimum \\
\hline $\begin{array}{l}\text { Persentase } \\
\text { keluarga pra } \\
\text { sejahtera }\left(\mathrm{X}_{1}\right)\end{array}$ & 4,732 & 30,039 & 0,040 & 39,010 \\
\hline $\begin{array}{l}\text { Persentase } \\
\text { keluarga } \\
\text { sejahtera tahap I } \\
\left(\mathrm{X}_{2}\right)\end{array}$ & 23,662 & 263,156 & 3,130 & 87,900 \\
\hline $\begin{array}{l}\text { Persentase bukan } \\
\text { peserta KB aktif }\end{array}$ & 22,375 & 299,588 & 0,260 & 86,200 \\
\hline $\begin{array}{l}\text { Persentase } \\
\text { peserta yang } \\
\text { tidak } \\
\text { menggunakan } \\
\text { MKJP }\left(\mathrm{X}_{4}\right) \\
\text { Persentase kepala }\end{array}$ & 60,941 & 311,510 & 16,040 & 91,080 \\
\hline $\begin{array}{l}\text { keluarga yang } \\
\text { tidak bekerja } \\
\left(\mathrm{X}_{5}\right)\end{array}$ & 14,939 & 118,638 & 0,067 & 48,780 \\
\hline
\end{tabular}

Rata-rata persentase keluarga pra sejahtera di Kota Surabaya pada tahun 2015 sebesar 4,732 persen dengan data bervariasi sebesar 30,039. Nilai minimum persentase keluarga pra sejahtera sebesar 0,04 persen pada Kelurahan Menanggal dan nilai maksimum sebesar 39,010 persen pada Kelurahan Made. Rata-rata persentase keluarga sejahtera tahap I sebesar 23,662 persen dengan data bervariasi sebesar 263,156. Nilai minimum persentase keluarga sejahtera tahap I sebesar 3,130 persen pada Kelurahan Jeruk dan nilai maksimum sebesar 87,90 persen pada Kelurahan Bringin.

Rata-rata persentase bukan peserta KB aktif di Kota Surabaya pada tahun 2015 sebesar 22,375 dengan data bervariasi sebesar 299,588. Nilai minimum persentase bukan peserta KB aktif sebesar 0,360 persen pada Kelurahan Tenggilis Mejoyo dan nilai maksimum sebesar 86,20 persen pada Kelurahan Tembok Dukuh. Rata-rata persentase peserta yang tidak menggunakan MKJP sebesar 60,941 persen dengan data bervariasi sebesar 311,510 persen. Nilai minimum persentase peserta yang tidak menggunakan MKJP sebesar 16,04 persen pada Kelurahan Lontar dan nilai maksimum sebesar 91,08 persen pada Kelurahan Kalisari. Rata-rata persentase kepala keluarga yang tidak bekerja di Kota Surabaya pada tahun 2015 sebesar 14,939 persen dengan data bervariasi sebesar 118,638 . Nilai minimum persentase kepala keluarga yang tidak bekerja sebesar 0,67 persen pada Kelurahan Kebonsari dan nilai maksimum sebesar 48,78 persen pada Kelurahan Pucang Sewu. 


\section{B. Deteksi Multikolinieritas}

Deteksi multikolinieritas digunakan untuk mengetahui ada tidaknya korelasi yang tinggi antar variabel dependen.

Tabel 4.

Hasil Deteksi Multikolinieritas

\begin{tabular}{lc}
\hline \hline \multicolumn{1}{c}{ Variabel Dependen } & VIF \\
\hline Persentase keluarga pra sejahtera & 1,113 \\
Persentase keluarga sejahtera tahap I & 1,112 \\
Perssentase bukan peserta KB aktif & 1,076 \\
Persentase peserta yang tidak menggunakan MKJP & 1,034 \\
Persentase kepala keluarga yang tidak bekerja & 1,077 \\
\hline \hline
\end{tabular}

Tabel 4 tersebut menunjukkan bahwa tidak terjadi kasus multikolinieritas atau tidak adanya korelasi antar variabel dependen yang digunakan karena nilai VIF $<10$.

\section{Pengelompokkan Kelurahan Di Kota Surabaya}

Analisis klaster dalam pengelompokkan ini menggunakan empat metode analisis hirarki yaitu metode single linkage, complete linkage, average linkage, dan metode ward's. Penentuan banyaknya kelompok yang paling optimum dari masing-masing metode akan dilihat berdasarkan Pseudo F.

Tabel 5.

Pseudo F untuk Masing-Masing Metode Pengelompokkan

\begin{tabular}{lcllr}
\hline \hline Metode & $\mathrm{g}=2$ & $\mathrm{~g}=3$ & $\mathrm{~g}=4$ & $\mathrm{~g}=5$ \\
\hline Single linkage & 5,782 & 14,211 & 11,754 & 9,860 \\
Complete linkage & 23,123 & 35,296 & 49,414 & 40,260 \\
Average linkage & 23,123 & 13,665 & 25,797 & 20,843 \\
Ward's & 30,262 & 40,484 & 42,914 & 48,360 \\
\hline \hline
\end{tabular}

Metode single linkage didapatkan Pseudo $F$ tertinggi ketika terbentuk kelompok sebanyak tiga kelompok. Metode complete linkage dan average linkage memiliki nilai Pseudo $F$ tertinggi ketika terbentuk kelompok sebanyak empat kelompok. Metode ward's didapatkan Pseudo $F$ tertinggi ketika terbentuk kelompok sebanyak lima kelompok

Rasio $S_{w}$ dan $S_{b}$ berdasarkan banyaknya kelompok optimum yang terbentuk berdasarkan Pseudo $F$ yang akan disajikan pada Tabel 7 berikut:

Tabel 6.

Perbandingan Rasio

\begin{tabular}{lcccc}
\hline \hline \multicolumn{1}{c}{ Metode } & $\begin{array}{c}\text { Kelompok } \\
\text { optimum }\end{array}$ & \multicolumn{1}{c}{$S_{w}$} & \multicolumn{1}{c}{$S_{b}$} & Rasio \\
\hline $\begin{array}{l}\text { Single linkage } \\
\begin{array}{l}\text { Complete } \\
\text { linkage }\end{array}\end{array}$ & 3 & 31,024 & 3,573 & 8,683 \\
$\begin{array}{l}\text { Average } \\
\text { linkage }\end{array}$ & 4 & 8,129 & 3,577 & 2,273 \\
Ward's & 4 & 10,514 & 4,580 & 2,296 \\
\hline \hline
\end{tabular}

Metode ward's merupakan metode pengelompokkan yang terbaik dalam mengelompokkan kelurahan di Kota Surabaya berdasarkan kriteria pembentukan Kampung KB karena memiliki rasio terendah dibandingkan dengan metode lainnya.

Hasil pengelompokkan menunjukkan bahwa masingmasing anggota kelompok terdiri dari 48 kelurahan, 10 kelurahan, 20 kelurahan, 38 kelurahan, dan 29 kelurahan di Kota Surabaya. Berikut merupakan rincian anggota pada masing-masing kelompok: a. Kelompok 1

Kelurahan Keputran, Dr. Sutomo, Tegalsari, Wonorejo, Kedungdoro, Embong Kaliasin, Ketabang, Genteng, Peneleh, Kapasari, Alon-Alon Contong, Jepara, Morokrembangan, Kemayoran, Kapas Madya Baru, Baratajaya, Pucang Sewu, Kertajaya, Gubeng, Airlangga, Mojo, Gebang Putih, Sawunggaling, Wonokromo, Jagir, Ngagelrejo, Ngagel, Darmo, Waru Gunung, Karang Pilang, Siwalankerto, Margorejo, Pagesangan, Kbonsari, Jambangan, Karah, Banjarsugihan, Putat Gede, Sonokwijenan, Simomulyo, Sukomanunggal, Simomulyo Baru, Tambak Sarioso, Asemrowo, dan Babat Jerawat.

b. Kelompok 2

Kelurahan Tembok Dukuh, Bulak Banteng, Tambak Wedi, Jemur Wonosari, Bendul Merisi, Sidosermo, Sememi, Kandangan, Tambak Oso Wilangon, Romo Kalisari.

c. Kelompok 3

Kelurahan Bubutan, Gundih, Bongkaran, Nyamplungan, Krembangan Utara, Perak Timur, Perak Utara, Ampel, Sidotopo, Pegirian, Wonokusumo, Manyar Sabrangan, Banyu Urip, Kupang Krajan, Petemon, Sumberejo, Made, Bringin, Sambikerep, dan Lontar.

d. Kelompok 4

Kelurahan Ujung, Dupak, Perak Barat, Krembangan Selatan, Tanah Kalikedinding, Sidotopo Wetan, Sukolilo, Kenjeran, Kedung Cowek, Pacar Keling, Pacar Kembang, Ploso, Tambak Sari, Rangkah, Gading, Dukuh Setro, Kendangsari, Tenggilis Mejoyo, Panjang Jiwo, Rungkut Menanggal, Rungkut Tengah, Gunung Anyar, Gunung Anyar Tambak, Nginden Jangkungan, Ssemolowaru, Medokan Semampir, Keputih, Klampis Ngasem, Menur Pumpungan, Mulyorejo, Kejawan Putih Tambak, Kalisari, Dukuh Sutorejo, Kalijudan, Pakis, Putat Jaya, Sawahan, dan Sumur Welut.

e. Kelompok 5

Kelurahan Bulak, Kebraon, Kedurus, Gunung Sari, Dukuh Pakis, Pradah Kali Kendal, Dukuh Kupang, Balas Krumpik, Babatan, Wiyung, Jajar Tunggal, Dukuh Menanggal, Gayungan, Ketintang, Tandes, Karangpoh, Balongsari, Manukan Wetan, Genting Kalianak, Bangkingan, Lidah Wetan, Lidah Kulon, Jeruk, Lakarsantri, Pakal, Benowo, dan Sumberejo.

\section{Evaluasi Hasil Pengelompokkan}

Evaluasi hasil pengelompokkan dilakukan dengan One Way MANOVA. MANOVA digunakan untuk menguji apakah terdapat perbedaan yang signifikan antar kelompok yang telah terbentuk.

Pengujian asumsi distribusi normal multivariat dilakukan dengan Uji Shapiro Wilk. Hipotesis yang digunakan adalah sebagai berikut :

$\mathrm{H}_{0}: F(X)=N(\mu, \Sigma)$ data berdistribusi normal multivariat $\mathrm{H}_{1}: F(X) \neq N(\mu, \Sigma)$ data tidak berdistribusi normal multivariat

Taraf signifikan sebesar $\alpha=0,05$

Hasil pengujian Shapiro Wilk disajikan pada Tabel 7.

Tabel 7 menunjukkan hasil pengujian asumsi distribusi normal multivariat. Keputusan yang didapatkan adalah $\mathrm{H}_{0}$ 
ditolak karena $W^{*}>c_{\alpha ; n, p}$ artinya data kriteria pembentukan kampung KB tidak berdistribusi normal multivariat.

Tabel 7.

Hasil Uji Shapiro Wilk

\begin{tabular}{ccc}
\hline \hline$W^{*}$ & $\mathrm{P}$-value & $\mathrm{c}_{\alpha, \mathrm{n}, \mathrm{p}}$ \\
\hline 0,767 & $8,785 \times 10^{-14}$ & 0,051 \\
\hline \hline
\end{tabular}

Uji Box's M digunakan untuk menguji apakah matriks varians kovarians homogen. Hipotesis yang digunakan dalam uji Box's M adalah sebagai berikut :

Hipotesis :

$\mathrm{H}_{0}: \boldsymbol{\Sigma}_{1}=\boldsymbol{\Sigma}_{2}=\boldsymbol{\Sigma}_{3}=\boldsymbol{\Sigma}_{4}=\boldsymbol{\Sigma}_{5}=\mathbf{0}$

$\mathrm{H}_{1}$ : minimal ada satu $\boldsymbol{\Sigma}_{i} \neq \boldsymbol{\Sigma}_{j}$ dimana $i \neq j$ dan

$i, j=1,2,3,4,5$

Hasil uji Box's M akan ditampilkan dalam Tabel 8 sebagai berikut:

Tabel 8.

Hasil Uji Homogenitas Matriks Varians Kovarians

\begin{tabular}{cccr}
\hline \hline $\mathrm{C}$ & $\begin{array}{c}\text { Derajat } \\
\text { bebas }\end{array}$ & P-value & \multicolumn{1}{c}{$\chi_{0,05(60)}^{2}$} \\
\hline 294,160 & 60 & 0,000 & 79,082 \\
\hline \hline
\end{tabular}

Keputusan yang didapatkan dengan taraf signifikan sebesar 0,005 adalah $\mathrm{H}_{0}$ ditolak karena $\mathrm{C}>79,082$. Artinya data tentang kriteria pembentukan Kampung KB di Kota Surabaya tidak memenuhi asumsi homogenitas matiks varians kovarians.

Analisis One Way MANOVA ini menggunakan statistik uji Pillai's Trace karena merupakan statistik uji yang paling cocok digunakan jika asumsi distribusi normal multivariat dan homogenitas matriks varian kovarians tidak terpenuhi. Langkah selanjutnya yaitu melakukan One Way MANOVA dengan hipotesis sebagai berikut.

Hipotesis :

$\mathrm{H}_{0}: \tau_{1}=\tau_{2}=\tau_{3}=\tau_{4}=\tau_{5}=\mathbf{0}$

$\mathrm{H}_{1}$ : minimal ada satu $\boldsymbol{\tau}_{i} \neq \mathbf{0}$ dimana $i=1,2,3,4,5$

Tabel 9.

Hasil MANOVA

\begin{tabular}{lcccll}
\hline \hline $\begin{array}{l}\text { Statistik } \\
\text { Uji }\end{array}$ & Nilai & F & $\begin{array}{l}\text { Derajat } \\
\text { Bebas } \\
\text { Hipotesis }\end{array}$ & $\begin{array}{l}\text { Derajat } \\
\text { Bebas } \\
\text { Eror }\end{array}$ & P-Value \\
\hline Pillai's & 2,173 & 32,575 & 20,00 & 548,00 & 0,00
\end{tabular}

Trace

Keputusan yang didapatkan berdasarkan Tabel 9 dengan taraf signifikan 0,05 adalah $\mathrm{H0}$ ditolak karena $\mathrm{F}>1,589$. Artinya terdapat perbedaan antar kelompok yang terbentuk berdasarkan lima variabel atau kriteria yang digunakan.

\section{E. Karakteristik Setiap Kelompok}

Berikut adalah perbandingan rata-rata tiap variabel dependen untuk mengetahui karakteristik masing-masing kelompok.

Tabel 10.

Rata-Rata Setiap Variabel Pada Masing-Masing Kelompok

\begin{tabular}{crrrrr}
\hline \hline Variabel & \multicolumn{1}{c}{ Kel. 1 } & \multicolumn{1}{c}{ Kel. 2 } & \multicolumn{1}{c}{ Kel. 3 } & \multicolumn{1}{c}{ Kel. 4 } & \multicolumn{1}{c}{ Kel. 5 } \\
\hline$X_{1}$ & 3,627 & $\mathbf{8 , 2 5 9}$ & 6,978 & 5,207 & 3,095 \\
$X_{2}$ & 24,161 & 14,054 & $\mathbf{5 3 , 8 3 5}$ & 19,941 & 10,250 \\
$X_{3}$ & 26,198 & $\mathbf{7 1 , 8 2 4}$ & 19,625 & 11,507 & 15,397 \\
$X_{4}$ & 58,822 & 72,165 & 50,529 & $\mathbf{7 7 , 2 2 1}$ & 39,381 \\
$X_{5}$ & 20,812 & $\mathbf{2 1 , 1 2 5}$ & 9,268 & 11,543 & 11,849 \\
\hline \hline
\end{tabular}

Keterangan :

Bold : kriteria pembentukan Kampung KB yang kurang baik a. Kelompok pertama

Kelompok pertama memiliki kondisi ekonomi dan capaian kriteria utama pembentukan Kampung KB yang cukup baik. Hal tersebut ditunjukkan oleh rata-rata persentase keluarga sejahtera dan rata-rata persentase keluarga sejahtera tahap I yang cukup rendah. Kelompok pertama juga memiliki capaian kriteria khusus pembentukan Kampung KB yaitu capaian program KB yang cukup baik. Hal tersebut ditunjukkan oleh rata-rata persentase bukan peserta $\mathrm{KB}$ aktif dan rata-rata persentase peserta yang tidak menggunakan MKJP cukup rendah. Namun, Tabel 10 menunjukkan bahwa rata-rata persentase peserta yang tidak menggunakan MKJP yang lebih dari 50,000 persen yaitu sebesar 58,822 persen. Pemerintah khususnya BKKBN sebaiknya lebih meningkatkan kembali program KIE (Komunikasi, Informasi, dan Edukasi) MKJP serta meningkatkan kegiatan penyuluhan $\mathrm{KB}$ di balai penyuluhan masing-masing wilayah khusunya kelurahan yang ada di kelompok pertama.

b. Kelompok kedua

Kelompok kedua memiliki kondisi ekonomi dan capaian kriteria utama yang kurang baik. Hal tersebut ditunjukkan oleh rata-rata persentase keluarga pra sejahtera dan rata-rata persentase kepala keluarga yang tidak bekerja yang paling tinggi diantara kelompok lainnya. Pemerintah khususnya BKKBN sebaiknya lebih meningkatkan dan mengimplementasi program Keluarga Harapan. Program Keluarga Harapan merupakan program perlindungan sosial yang memberikan bantuan uang tunai kepada Rumah Tangga Sangat Miskin (RTSM) dengan syarat dapat memenuhi kewajiban terkait pendidikan dan kesehatan Kelompok kedua juga memiliki capaian kriteria khusus Kampung KB yaitu capaian program KB yang rendah. Hal tersebut ditunjukkan oleh rata-rata persentase bukan peserta $\mathrm{KB}$ yang paling tinggi diantara kelompok yang lainnya. Pemerintah khususnya BKKBN sebaiknya meningkatkan kembali program KIP konseling, pelayanan $\mathrm{KB}$ dan kesehatan reproduksi di kelurahan yang ada di kelompok kedua. Meskipun bukan yang paling tinggi, namun kelompok kedua juga memiliki rata-rata persentase peserta yang tidak menggunakan MKJP cukup tinggi, artinya masih banyak PUS yang belum memiliki kesadaran akan pentingnya MKJP. BKKBN juga seharusnya meningkatkan program KIE MKJP di kelurahan-kelurahan yang ada di kelompok kedua.

c. Kelompok ketiga

Kelompok ketiga memiliki capaian kriteria utama Kampung KB yang kurang baik. Hal tersebut ditunjukkan oleh rata-rata persentase keluarga pra sejahtera yang cukup tinggi dan ratarata persentase keluarga sejahtera tahap I yang paling tinggi. Artinya kelurahan-kelurahan yang masuk kelompok ketiga masih memiliki banyak keluarga miskin. Pemerintah sebaiknya lebih meningkatkan sosialisasi dan mengimplementasikan program Keluarga Harapan serta melakukan perlindungan orang miskin dan anak terlantar. Kelompok ketiga juga memiliki capaian program KB yang cukup baik. Hal tersebut dapat ditunjukkan oleh rata-rata persentase bukan peserta $\mathrm{KB}$ aktif dan rata-rata persentase peserta yang tidak menggunakan MKJP yang rendah. Namun, Tabel 4.8 menunjukkan bahwa rata-rata persentase peserta yang tidak menggunakan MKJP 
yang sekitar 50,000 persen yaitu sebesar 50,529 persen. Pemerintah khususnya BKKBN lebih meningkatkan kembali program KIE (Komunikasi, Informasi, dan Edukasi) MKJP serta meningkatkan kegiatan penyuluhan $\mathrm{KB}$ di balai penyuluhan masing-masing wilayah khusunya kelurahan yang ada di kelompok ketiga.

\section{d. Kelompok keempat}

Kelompok keempat memiliki capaian kriteria utama Kampung KB yang cukup baik. Hal tersebut ditunjukkan oleh rata-rata persentase keluarga pra sejahtera, rata-rata persentase keluarga sejahtera tahap I, dan rata-rata persentase kepala keluarga yang tidak bekerja cukup rendah. Artinya kelurahankelurahan yang ada di kelompok keempat memiliki keluarga miskin yang tidak banyak. Kelompok keempat juga memiliki rata-rata persentase bukan peserta KB aktif yang paling rendah. Artinya PUS di kelurahan yang berada di kelompok keempat memiliki kesadaran ber-KB yang tinggi. Namun, kelompok keempat juga memiliki rata-rata persentase peserta yang tidak menggunakan MKJP yang paling tinggi diantara kelompok yang lainnya. Artinya PUS di kelurahan yang berada di kelompok keempat lebih banyak menggunakan kontrasepsi seperti suntik, pil, dan kondom. Pemerintah khususnya BKKBN lebih meningkatkan kembali program KIE (Komunikasi, Informasi, dan Edukasi) MKJP serta meningkatkan kegiatan penyuluhan KB di balai penyuluhan masing-masing wilayah khusunya kelurahan yang ada di kelompok keempat.

\section{e. Kelompok kelima}

Kelompok kelima memiliki capaian kriteria utama Kampung KB yang cukup baik. Hal tersebut ditunjukkan oleh rata-rata persentase keluarga pra sejahtera dan rata-rata persentase keluarga sejahtera tahap I yang paling rendah diantara kelompok lainnya. Artinya kelurahan-kelurahan yang berada di kelompok kelima memiliki keluarga miskin yang sangat sedikit dan perekonomian yang lebih baik dibandingkan dengan kelompok lainnya. Kelompok kelima juga memiliki capaian program KB yang cukup baik. Hal tersebut ditunjukkan oleh rata-rata persentase bukan peserta KB aktif yang cukup rendah. Artinya sebagian besar PUS di kelurahan-kelurahan yang berada dikelompok kelima memiliki kesadaran yang tinggi akan pentingnya ber-KB. Selain itu, kelompok kelima juga memiliki rata-rata persentase peserta yang tidak menggunakan MKJP paling rendah dibandingkan dengan kelompok lainnya. Hal Artinya sebagian besar PUS di kelurahan-kelurahan yang berada dikelompok kelima menggunakan metode kontrasepsi jangka panjang seperti IUD, implan, MOP, dan MOW.

Pemilihan kelompok yang paling tidak baik dilakukan dengan membandingkan banyaknya variabel yang memenuhi kriteria pembentukan Kampung KB di setiap kelompok, yaitu kelompok yang memiliki rata-rata tertinggi disetiap variabel. Tabel 10 menunjukkan bahwa pada kelompok kedua memiliki tiga variabel atau kriteria pembentukan Kampung KB yang kurang baik. Ketiga variabel tersebut yaitu rata-rata persentase keluarga pra sejahtera, rata-rata persentase bukan peserta KB, dan rata-rata persentase kepala keluarga yang tidak bekerja yang paling tinggi diantara kelompok lainnya. BKKBN sebaiknya lebih memperhatikan sepuluh kelurahan yang ada di kelompok kedua dalam pembentukan Kampung KB di Kota Surabaya.

Pemilihan kelompok yang paling baik dilakukan dengan membandingkan banyaknya variabel yang memiliki rata-rata paling rendah. Tabel 10 menunjukkan bahwa pada kelompok kelima memiliki tiga variabel atau kriteria pembentukan Kampung KB yang rata-ratanya paling rendah.

\section{KESIMPULAN}

Metode pengelompokkan terbaik untuk mengelompokkan kelurahan di Kota Surabaya berdasarkan kriteria Kampung KB adalah metode ward's dengan banyaknya kelompok optimum yang terbentuk adalah lima kelompok. Masing-masing kelompok terdiri dari 48 kelurahan, 10 kelurahan, 20 kelurahan, 38 kelurahan, dan 29 kelurahan. Hasil evaluasi pengelompokkan dengan menggunakan One Way MANOVA adalah terdapat perbedaan antar kelompok kelurahan yang terbentuk berdasarkan kriteria pembentukan Kampung KB.

\section{DAFTAR PUSTAKA}

[1] A. Hartik, "Kepala BKKBN : Laju Pertumbuhan Penduduk 4 Juta Per Tahun, Idealnya 2 Juta," Kompas.com, 2016.

[2] BPS and BKKBN, "Survei Demografi dan Kesehatan Indonesia 2012," Jakarta, 2012.

[3] BKKBN, "Kampung KB, Upaya Pemerintah Membumikan Kembali Keluarga Berencana," bkkbn.go.id, 2018. [Online]. Available: https://www.bkkbn.go.id/detail-post/kampung-kb-upayapemerintah-membumikan-kembali-keluarga-berencana. [Accessed: 20-Jan-1BC].

[4] BKKBN, "Laporan Hasil monitoring dan Evaluasi," Surabaya, 2016.

[5] Dinas Pengendalian Penduduk, Surabaya, and Pemberdayaan Perempuan dan Perlindungan Anak Kota Surabaya, "Launching Kampung KB Kota Surabaya di Kecamatan Semampir," 2016.

[6] R. Johnson, Statistics Principle and Method, 6th ed. USA: John Wiley \& Sons Inc, 2010.

[7] R. A. Johnson and D. W. Winchern, Applied Multivariat Statistical Analysis, 6th ed. New Jersey: Pearson Education, 2007.

[8] R. Walpole, Pengantar Metode Statistika, 3rd ed. Jakarta: Bumi Aksara, 1995.

[9] N. D. Nachrowi and H. Usman, "Pendekatan Populer dan Praktris Ekonometrika untuk Analisis Ekonomi dan Keuangan," Jakarta, 2006

[10] A. R. Orpin and V. E. Kostylev, "Toward a Statistically Valid Method of Textural Sea Floor Characterization of Benthic Habitats," Mar. Geol., pp. 209-222, 2006.

[11] M. J. Bunkers and R. M. James, "Definition of Climate Region in The Northern Plains Using an Objective Cluster Modification Technique," J. Clim., pp. 130-146, 1996.

[12] J. A. Alva and E. G. Estrada, "A Generalization of Shapiro-Wilk's Test for Multivariate Normality," Commun. Stat. Methods, vol. 38, no. 11, pp. 1870-1883, 2009.

[13] A. Rencher, Methods of Multivariate Analysis, 2nd ed. America: John Wiley \& Sons, 2002.

[14] Anindita, "Menyisir Pinggiran Indonesia dengan Kampung KB," 2016. 